\title{
OPTIMIZATION OF ENERGY IN PUBLIC BUILDINGS
}

\author{
Krishna A. Joshi ${ }^{1}$, A.R. Kambekar ${ }^{2}$ \\ ${ }^{1}$ PG. Student, ${ }^{2}$ Assistant Professor, Construction Management, CED, SPCE Andheri (West), Mumbai, \\ Maharashtra, 400 058, krishna.a.joshi@gmail.com
}

\begin{abstract}
Building construction and infrastructure industry is one the fastest developing industry and a major energy consuming sector in general. Public buildings which consists schools, colleges, corporate offices, government offices which are growing day by day, they require tremendous amount of energy resources for construction of buildings for utilization of service. This paper mainly focuses on the embodied energy of materials used in construction of college building located in Badlapur (West), Kalyan city of Thane district in Maharashtra and comparision is done with different alternative materials in order to reduce the energy of building.
\end{abstract}

Keywords: Energy Optimization, Public Buildings, Embodied Energy, Alternative Materials.

$* * *$

\section{INTRODUCTION}

The public buildings which include schools, colleges, and offices consume a considerable amount of energy and other natural resources. Buildings in India consume about $20 \%$ of the country's total electricity and have a significant impact on the environment and resources indicating the need to develop green buildings .Our country is witnessing tremendous growth in construction sector,so here it is considered to be one of the largest economic activites which grows at an average rate of $9.5 \%$ as compared to global average rate of 5\%[4]. Use of those construction materials which are posing threat to the environment are also growing at a alarming rate. So construction industry therefore needs to contribute towards preserving environment. Minimising the consumption of the conventional materials by using alternative materials, methods \& techniquies can result in scope for considerable energy savings as well as reduction of $\mathrm{CO}_{2}$ emission[1]. A large quantity of $\mathrm{CO}_{2}$ is emitted to the atmosphere through whole life cyce of a building, so choice of building material is very important in reducing the energy content of building

\section{ALTERNATIVE BUILDING MATERIALS}

The art and science of building construction commeneced with the use of natural materials like stone, soil ,leaves[2].Materials for earthen construction such as hydrated lime ,clay ,mud bricks compressed earth block sand rammed earth have been known and used many years allover the world .There is a growing interest in these Building materials as sustainable alternatives to traditional bricks, concrete and wood [4]. A high proportion of this energy is used to produce a small number of key materials such as concrete, mortar, plaster and bricks. The highest energy is used in the manufacture of aluminum, copper, stainless steel and plastics (primary energy requirements for production very from 250 Giga Joules (GJ)/ ton to $100 \mathrm{GJ} /$ ton) followed by glass, cement and plaster boards (primary energy requirements for production vary from $60 \mathrm{GJ} /$ ton to $10 \mathrm{GJ} / \mathrm{ton}$ ). The energy embodied in a building is estimated to vary between 15 and 20 years of its energyconsumption in use[8].

\section{EMBODIED ENERGY}

The energy in buildings may be divided into two category Embodied energy and operational energy. Embodied Energy is the energy requirement to construct and maintain the premises for example, to construct a brick wall, the energy required to make the bricks, transport them to site, and lay them. Operational energy is the energy requirement of the building during its life from commissioning to demolition for example, the energy used to heat and cool the premises, run the equipments and light rooms .To calculate the energy consumption by public building, a college building is taken as case study which consists of two buildings of G+1 R.C.C. framed structure located in Badlapur near city of Kalyan in Thane district of Maharashtra state. The existing public building considered in this paper as an engineering institution having a total built up area of around $3701.2 \mathrm{~m}^{2}$.

Energy consumption of any building depends upon the usage of building for which it is constructed i.e. the service which it provides to the people. This paper deals with the educational structure which consists of classrooms, laboratories, and machines etc. During the construction of structure the materials which are used for building requires huge amount of energy while manufacturing, transporting, assembling, installation and destruction of some structures if needed. This energy is termed as embodied energy of materials and Operational Energy is the total energy which is needed for maintenance of the building services during the entire life cycle of structure. Estimated embodied energy in the material is shown in Table 1 and Table 2 shows energy consumption per person and per square meter of the building and embodied 
energy index considering 150 personnel working at any moment of time.

\section{METHODOLOGY ADOPTED}

Methodology adopted for optimization of energy for college building is as follows:
- Estimation of energy and carbon emission of building material.

- Cost estimation of material used.

- Comparison with alternative materials for energy, carbon emission and cost.

- Selection of best option.

Table 1 Embodied energy coefficients

\begin{tabular}{|l|l|l|}
\hline Material & Energy & Type of Energy \\
\hline Clay Bricks & $(3.75-4.75)$ per brick[1]. & Coal /Wood /Rice Husk \\
\hline $\begin{array}{l}\text { AAC Blocks/Hollow Concrete } \\
\text { blocks }\end{array}$ & $\begin{array}{l}(1.3-1.62) \text { per brick[1]. } \\
(3.5) \text { per brick[7] }\end{array}$ & Coal +Electricty \\
\hline Fly ash Bricks & $(1.00-1.35) /$ per brick[2]. & Coal +Electricty \\
\hline Cement & $(4.2-5.85) \mathrm{MJ} / \mathrm{KG}[1]$. & Coal +Electricity \\
\hline Ceramics & $180 \mathrm{MJ} / \mathrm{SQM}[7]$. & Diesel \\
\hline Kota & $79.8 \mathrm{MJ}$ SQM[9]. & Fuel oil \\
\hline Terrazzo & $92.7 \mathrm{MJ} / \mathrm{SQM}[9]$. & Fuel oil \\
\hline
\end{tabular}

Table 2 Energy Estimation of Building (Case Study)

\begin{tabular}{|c|l|c|c|c|}
\hline $\begin{array}{c}\text { Sr. } \\
\text { No. }\end{array}$ & \multicolumn{1}{|c|}{ Material } & Unit & $\begin{array}{c}\text { Total } \\
\text { Quantity }\end{array}$ & $\begin{array}{c}\text { Total Embodied } \\
\text { Energy (MJ) }\end{array}$ \\
\hline 1 & Brick & Number & 225000 & 954000 \\
\hline 2 & Cement & Bag & 28865 & 873166 \\
\hline 3 & Aggregates & Cu.m. & 5660 & 848943 \\
\hline 4 & Sand & Cu.m. & 849 & 22277 \\
\hline 5 & Steel & Kg. & 350000 & 14735000 \\
\hline 6 & Paint & Kg.m. & 6550 & 45522 \\
\hline 7 & Aluminium & Kg. & 1000 & 340000 \\
\hline 8 & Glazing & Sq.m. & 6659 & 1480 \\
\hline 9 & Ceramic tile & \multicolumn{2}{|l}{} \\
\hline \multicolumn{2}{|l|}{ Total embodied energy for an engineering college building } & 19019008 \\
\hline
\end{tabular}

Table 3 Energy Index

\begin{tabular}{|c|l|c|c|}
\hline $\begin{array}{c}\text { Sr. } \\
\text { No. }\end{array}$ & \multicolumn{1}{|c|}{ Embodied Energy } & Embodied Energy (MJ) & $\begin{array}{c}\text { Embodied Energy } \\
(\mathbf{k W h})\end{array}$ \\
\hline 1 & Total Embodied Energy in all materials of the building & 19019008 & 5135132 \\
\hline 2 & Energy Consumption per person & 126793 & 34234 \\
\hline 3 & Energy consumption per square meter & 2535 & 685 \\
\hline
\end{tabular}


Table 1, 2, 3 depicts energy coefficients values and total energy estimation of said building and energy index respectively.Figure 1, 2 and 3 shows materials which have been used in the construction and is compared with the alternative energy efficient materials which have low embodied energy, carbon emission and cost. Table 4, 5 and 6 shows embodied energy, carbon emissions and cost of different materials of brick, cement and tile material. For brick masonry three options have been considered i.e. clay bricks which is normally used, fly ash bricks and autoclave aerated bricks (AAC). Figure 1 shows that cost of clay bricks is more as compared to fly ash bricks but is less costlier than AAC Blocks. Cement of two types are considered in this study i.e. ordinary Portland cement (OPC) and Portland pozzolana cement (PPC). It was observed that OPC has a higher embodied energy value than PPC and same is shown in Figure 2. When tiles are considered it was observed that ceramic tiles have higher energy value as well as higher cost compared to terrazzo tiles (Figure 3). Avg of Standard values of embodied energy and carbon emission in material (MJ/M3) are considered [1]. Cost of material is considered as per the local rates for locally available material.

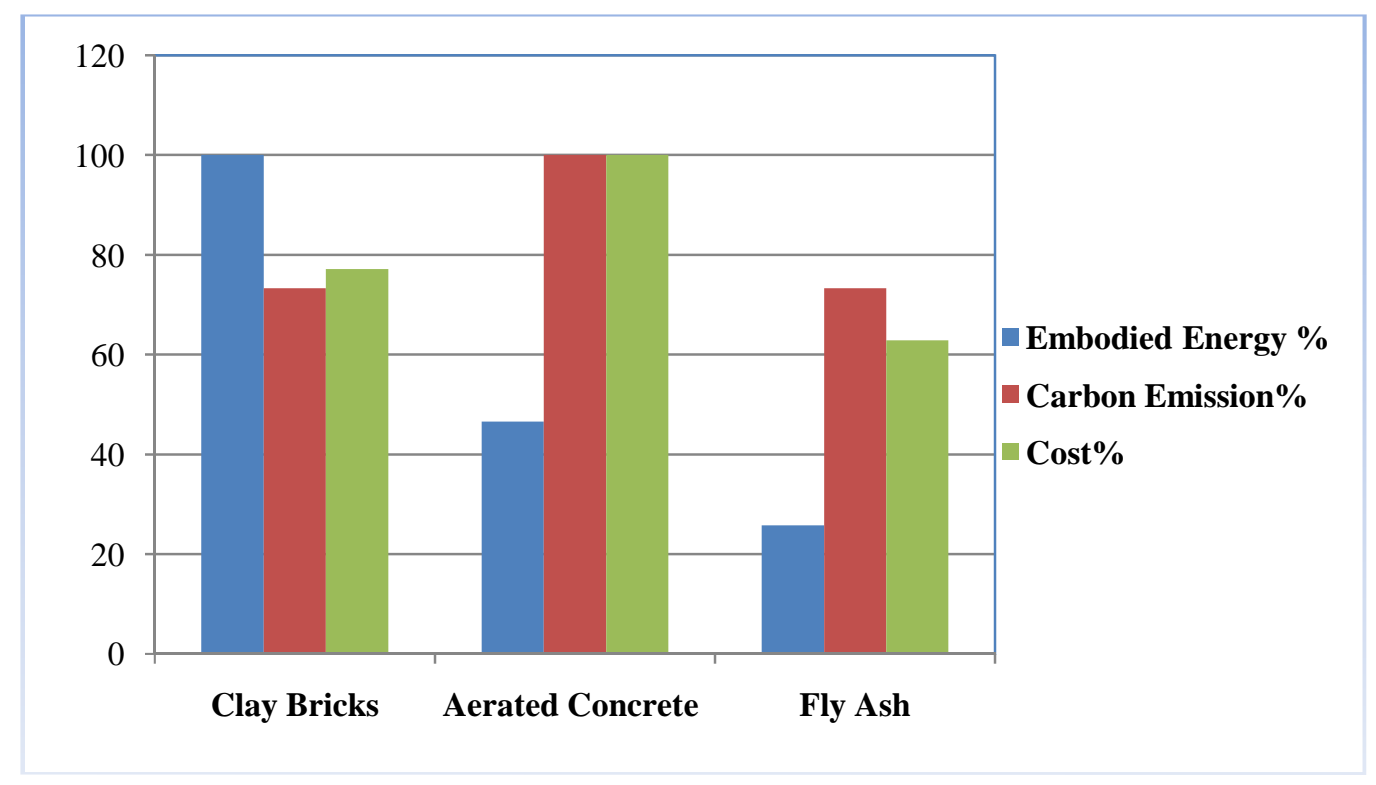

Figure 1. Embodied energy, carbon emission and cost of brick material

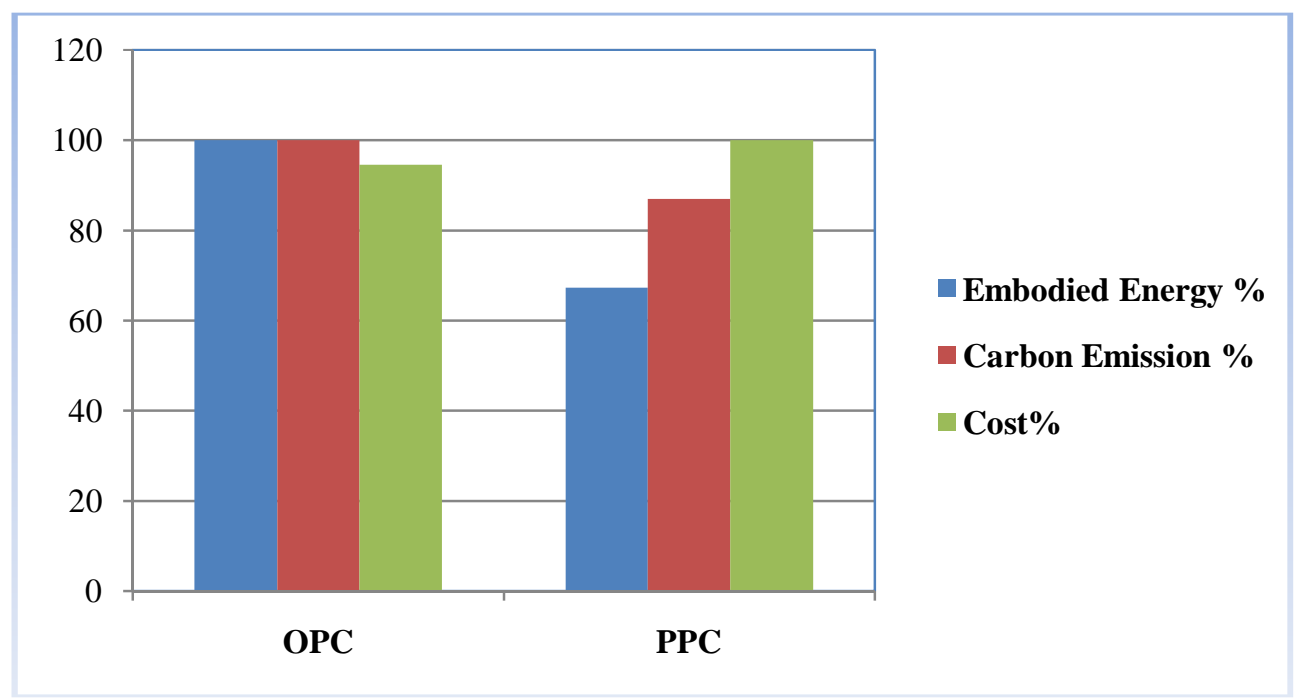

Figure 2. Embodied energy, carbon emission and cost of cement material 


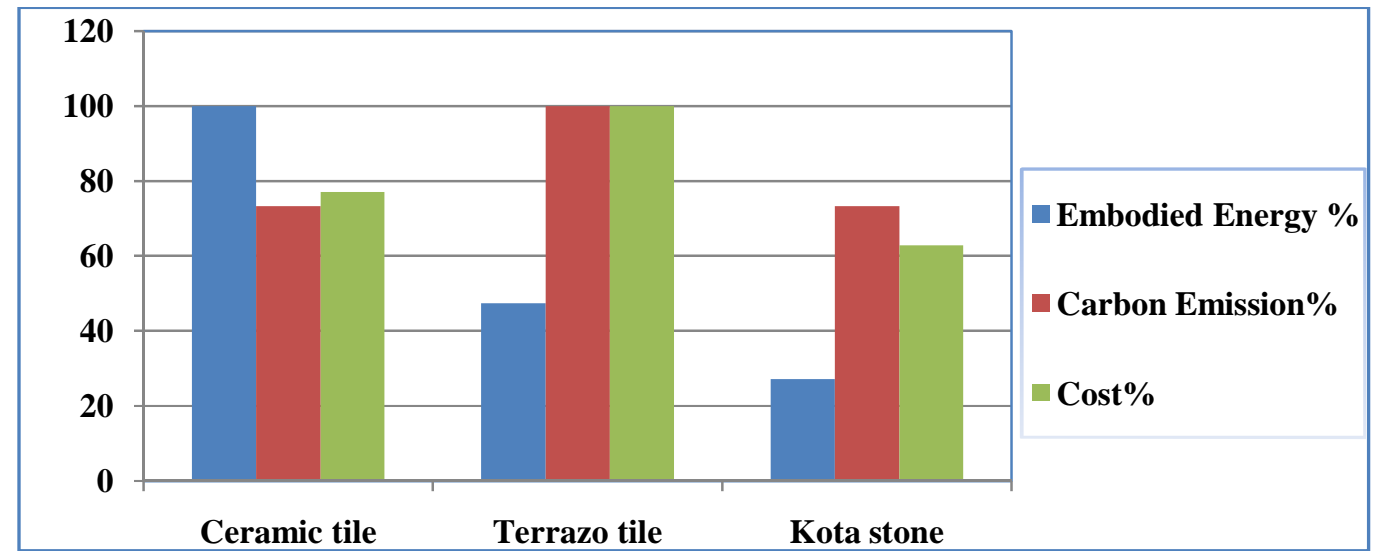

Figure 3. Embodied energy, carbon emission and cost of tiles

Table 4. Embodied energy and carbon emission and cost in bricks

\begin{tabular}{|l|l|c|c|c|c|c|}
\hline $\begin{array}{c}\text { Sr } \\
\text { No. }\end{array}$ & \multicolumn{1}{|c|}{ Types of bricks } & $\begin{array}{c}\text { Quantity } \\
\text { (Cu.m.) }\end{array}$ & $\begin{array}{c}\text { Embodied } \\
\text { energy (value) } \\
\left(\mathbf{M J}_{\mathbf{3}} \mathbf{M}^{\mathbf{3}}\right)\end{array}$ & $\begin{array}{c}\text { Embodied } \\
\text { energy } \\
\left(\mathbf{M J} / \mathbf{M}^{\mathbf{3}}\right)\end{array}$ & $\begin{array}{c}\text { Carbon } \\
\text { emission } \\
(\mathbf{C O} / \mathbf{K g})\end{array}$ & $\begin{array}{c}\text { Cost/ } \\
\text { cum }\end{array}$ \\
\hline 1 & Clay bricks & 436.89 & 3950 & 1725715.5 & 96.11 & 2700 \\
\hline 2 & $\begin{array}{l}\text { Autoclave aerated } \\
\text { concrete blocks }\end{array}$ & 436.89 & 2150 & 939313.5 & 131.067 & 3500 \\
\hline 3 & Fly ash & 436.89 & 1020 & 445627.8 & 96.11 & 2200 \\
\hline
\end{tabular}

Table 5. Embodied energy, carbon emission and cost of cement

\begin{tabular}{|l|l|l|c|c|c|c|}
\hline $\begin{array}{c}\text { Sr. } \\
\text { No. }\end{array}$ & $\begin{array}{l}\text { Types of } \\
\text { cement }\end{array}$ & $\begin{array}{c}\text { Quantity } \\
\text { (Cu.m.) }\end{array}$ & $\begin{array}{c}\text { Embodied energy } \\
\text { value } \\
\left(\mathbf{M J} / \mathbf{M}^{\mathbf{3}}\right)\end{array}$ & $\begin{array}{c}\text { Embodied energy } \\
(\mathbf{M J} / \text { /Sqm) }\end{array}$ & $\begin{array}{c}\text { Carbon } \\
\text { emission } \\
(\mathbf{K g} / \mathbf{C O})\end{array}$ \\
\hline 1. & OPC & 1010.275 & 840 & 848631 & 939.555 \\
\hline /cum
\end{tabular}

Table 6. Embodied energy, carbon emission and cost of tile

\begin{tabular}{|l|l|c|c|c|c|c|}
\hline \multicolumn{1}{|c|}{$\begin{array}{l}\text { Sr. } \\
\text { No. }\end{array}$} & $\begin{array}{l}\text { Types of } \\
\text { tiles }\end{array}$ & $\begin{array}{c}\text { Quantity of } \\
\text { Tile } \\
\text { (Sq.m.) }\end{array}$ & $\begin{array}{c}\text { Embodied energy } \\
\text { value } \\
\text { (MJ/SQM) }\end{array}$ & $\begin{array}{c}\text { Total embodied } \\
\text { energy } \\
\text { (MJ/Sq.m.) }\end{array}$ & $\begin{array}{c}\text { Carbon } \\
\text { emission } \\
\left(\mathbf{K g} / \mathbf{C O}_{2}\right)\end{array}$ & $\begin{array}{c}\text { Cost per } \\
\text { Sq.m. }\end{array}$ \\
\hline 1. & Ceramic tiles & 3329.59 & 180 & 599326.21 & 2463.896 & 1200 \\
\hline 2. & $\begin{array}{l}\text { Terrazzo } \\
\text { tiles }\end{array}$ & 3329.59 & 92.7 & 308652.99 & 399.55 & 700 \\
\hline 3. & $\begin{array}{l}\text { Kota } \\
\text { stone }\end{array}$ & 3329.59 & 79.8 & 265701.82 & 299.66 & 1000 \\
\hline
\end{tabular}




\section{CONCLUSIONS}

In this study embodied energy of a college building is estimated for different material. Comparision of embodied energy, carbon and cost of different material used is done with the traditionally used material. Based on the analysis of energy reduction of building materials by using available alternative material following conclusions are drawn.

- Total embodied energy of college building was found to be 19,01,9008 MJ for all materials.

- The use of flyash bricks if replaced by clay bricks saves around $1288825 \mathrm{MJ}$ and reducing consumption of energy by around $74.6 \%$ and also cost decreases by $14 \%$ and reduction in carbon emissions by $26.6 \%$

- AAC blocks reduces energy consumption by $45 \%$ but cost increases by $39 \%$.

- The use of PPC over OPC reduces energy consumption by $33 \%$ and carbon emissions by $13 \%$ with cost increament of $6 \%$.

- The use of Kota stone reduces energy consumption by $7 \%$ and carbon emissions by $1.6 \%$ when compared to Terrazo tile with increase in cost by $13 \%$.

\section{REFERENCES}

[1]. Reddy B.V.V Jagdish K.S, “Embodied Energy of Common and alternative building materials and technologies", Journal of Energy and Buildings ,(2003)Vol.3, pages 129-137.

[2].Reddy B.V.V "Sustainable materials for low carbon buildings"International Journal of Low- Carbon Technologies, Vol.4(2009), pages 175-181.

[3]. A Debnath, S.V.Singh ,Y.P Singh, Comparative assessment of energy requirements for different types of residential buildings in India, Energy and Buildings 23 (1995), 141-146.

[4]. Paul Joseph ,Svetlana Tretsiakova -Mcnally "Sustainable Non-Metallic Building Materials", Journal of Sustainability(2010), 2,pages 400-427

[5].Krishnakedar.S.Gumaste"Embodied Energy Computations in Buildings", International Journal of Cement Concrete Research, (2008),Vol.82, pages 1440-1445

[6]. Sonam.Shah , Mili Majumdar, "Study of Life Cycle Costing For Griha Rated Green Buildings In India" Suistanable Building Science, The Energy \& Research Institute

[7]. Ashok Kumar, D. Buddhi and D. S. Chauhan, "Indexing of Building Materials with Embodied ,Operational energy and Environmental sustainbility with Reference to Green Buildings"Journal of Pure and Applied Science Technology, Vol 2(1)(2012) pages 11-22.

[8].V.Suresh, "The Bulletin on Energy Efficiency", Vol. I (5 )(2001).

[9]. Directorate General Central Public Works Department CPWD "A HANDBOOK OF PLANNING OF OFFICE OF BUILDINGS”, (2013) 